\title{
Sharing Ideas and Expressions in Global Communities
}

\author{
Wolfgang Coy
}

There is now a vivid discussion of commercial aspects and the protection of intellectual artifacts, ideas and the forms how they are expressed. Though this discussion was for more than one and a half century focused on industrial societies it becomes now under the leadership of the U.S. a basic debate in shaping a global net of information societies. The debate becomes so intensive that some scholars like Lawrence Lessig consider intellectual property laws to become the central field of economic and legal argument in the beginning century. Others like the director general of the UN-related World Intellectual Property Organization WIPO Kamil Idris go so far to state "ideas are the new currency."

Intellectual property refers to creations of the mind like inventions, literary and artistic works, but also symbols, names, images, and designs used in commerce. In the present development there are three major distinct fields in the definition of sintellectual property<, namely patent law, copyright law, and the so-called minor IP laws of trademark and related rights.

History of patents is a story of privileges - feudal and statuary privileges announced by some litterae patentes, some open letter stating these privileges like the privilege to become an officer, to explore land recently discovered and occupied, but also to exploit certain techniques as an artisan or as manufacturer. These open letters were recognized by the authorities; they became open to the public once modern patent law was established. In fact it is this exchange of disclosed trade secrets against a temporary and regional monopoly to exploit these secrets.

The idea of copyright is one of different aspects of the production and distribution of printed work. It is situated between the notion of authorship and patents for printers and the rights of publishers or booksellers. While the right to print and sell copies is central to the anglo-american tradition of copyright, the notion of authorship is the basic term in the continental European definition of droits d'auteurs.

The protection of trademarks and other design aspects stems from different roots, founded in the regulation of guilds and trades.

All three types of intellectual property laws are different though they are sometimes considered to be closely related - as by the World Intellectual Property Organization WIPO, a specialized agency of the United Nations, that was made responsible for the $>$ Development

\footnotetext{
${ }^{1} \underline{\mathrm{http}} / / /$ www.wipo.int/about-wipo/en/dgo/dgki 2005.html

${ }^{1}$ This stems probably from the German >Als Adam grub und Eva spann, wo war da der Edelmann. Not so surprising the German Adam is a peasnat, while the English Adam is a weaver.
} 
of balanced international IP laws which are responsive to emerging needs; effective in encouraging innovation and creation; and sufficiently flexible to accommodate national policy objectives.< WIPO has actually 181 member states. Article 1 of the 1974 basic agreement between UN and WIPO defines as its prime task the spromotion of creative intellectual activity and the facilitation of the transfer of technology related to intellectual property to the developing countries in order to accelerate economic, social and cultural development.r However, it is somewhat questionable whether the present development in Intellectual Property Laws and Treaties is in fact accelerating economic, social and cultural development - or if it is constricting this development as others argue.

\section{On property of ideas}

Before we start to evaluate some ethical questions about these >rights we should consider the somewhat deeper question how property in the field of ideas, expression, art, or design may be justified - if at all. It may be helpful to explore this question from a historical point of view.

Property in the tradition of the Roman Law did not recognize a tradable sintellectual property right.< Property was restricted to mobile and immobile materials like land, houses, ships, cattle, and other personal or family belongings, including slaves, but it covered not wild animals, the sea, air, or similar commons. Ideas were beyond the roman notion of property though plagiarism of ideas or artistic expression was considered as misbehavior and that was common understanding in the European law tradition until the 17th century.

The justification of property was feudal - best exemplified in the age of feudal absolutism. The royal ruler received all power from god and past it via privileges to the nobility that gave itself further privileges to the less fortunate in the social arrangement.

This all was questioned in some revolts, most notable the peasant wars. >When Adam wove and Eve spun, where was then the nobleman. $2^{2}$ but it was essentially questioned by some philosophers of the enlightenment.

John Locke started like some later philosophers from three assumptions: God gave the world to all men, men are free and men may appropriate the wealth of the earth by his own labour. ${ }^{3}$

>Sec. 26. God, who hath given the world to men in common, hath also given them reason to make use of it to the best advantage of life, and convenience. The earth, and all that is therein, is given to men for the support and comfort of their being. And tho' all the fruits it naturally produces, and beasts it feeds, belong to mankind in common, as they are produced by the spontaneous hand of nature; and no body has originally a private dominion, exclusive of the rest of mankind, in any of them, as they are thus in their natural state: ...

\footnotetext{
${ }^{2}$ John Locke, Two Treatises of Government, Ch. V. "Of Property", 1690

${ }^{3}$ Jean-Jacques Rousseau, A Dissertation On the Origin and Foundation of the Inequality of Mankind, 1755
} 
>Sec. 27. Though the earth, and all inferior creatures, be common to all men, yet every man has a property in his own person: this no body has any right to but himself. The labour of his body, and the work of his hands, we may say, are properly his. Whatsoever then he removes out of the state that nature hath provided, and left it in, he hath mixed his labour with, and joined to it something that is his own, and thereby makes it his property. ...

\Sec. 28. He that is nourished by the acorns he picked up under an oak, or the apples he gathered from the trees in the wood, has certainly appropriated them to himself. No body can deny but the nourishment is his. I ask then, when did they begin to be his? when he digested? or when he eat? or when he boiled? or when he brought them home? or when he picked them up? and it is plain, if the first gathering made them not his, nothing else could. That labour put a distinction between them and common: that added something to them more than nature, the common mother of all, had done; and so they became his private right. And will any one say, he had no right to those acorns or apples, he thus appropriated, because he had not the consent of all mankind to make them his? Was it a robbery thus to assume to himself what belonged to all in common? If such a consent as that was necessary, man had starved, notwithstanding the plenty God had given him.<

Jean-Jacques Rousseau saw property as an acceptable concept only by some contrat social, a common understanding and balance of interests in a social contract defining law. All former property was appropriated illegitimately by force. >The first man who, having enclosed a piece of ground, bethought himself of saying 'This is mine', and found people simple enough to believe him, was the real founder of civil society. From how many crimes, wars, and murders, from how many horrors and misfortunes might not any one have saved mankind, by pulling up the stakes, or filling up the ditch, and crying to his fellows: >Beware of listening to this imposter; you are undone if you once forget that the fruits of the earth belong to us all, and the earth itself to nobody. $<^{4}$

Immanuel Kant followed this interpretation of property as a common contract. While he took a firm stand in the print and reprint of books, as the book represents the author's speech and the printer is bound to the author's consent to have it printed or not, Kant did not accept any >natural right $<$ of property - neither material nor intellectual. In >Metaphysics of Morals< (Metaphysik der Sitten), he claims only one universal single right for each individual, that of freedom and of free will. ${ }^{5}$ This right is essential: Because of this right a person may not be arbitrarily coerced. >Freedom (independence from being constrained by another's choice), insofar as it can coexist with the freedom of every other in accordance with a universal law, is the only original right belonging to every man by virtue of his humanity.<

\footnotetext{
${ }^{4}$ Though Kant sees that this right is by most societies neither given nor taken by its members. But he insists on the moral necessity of this free will.

5 Pierre-Joseph Proudhon, Qu'est-ce que la propriété? Recherche sur le principe du droit et du gouvernement, 1840 .
} 
As a consequence all property rights are only rights by tradition and contract. For Kant there are no >natural rights« of property.

In the 19th century the question of property was central in the discussion of social justice. Pierre-Joseph Proudhon demonstrated how questionable, relative, and arbitrary the notion of property is. In his often misunderstood and misquoted text: What is property? ${ }^{6}$ Proudhon starts with the sentences IIf I were asked to answer the following question: What is slavery? and I should answer in one word, It is murder, my meaning would be understood at once. No extended argument would be required to show that the power to take from a man his thought, his will, his personality, is a power of life and death; and that to enslave a man is to kill him.

$>$ Why, then, to this other question: What is property? may I not likewise answer, It is robbery, without the certainty of being misunderstood; the second proposition being no other than a transformation of the first?

$>$ Nevertheless, I build no system. I ask an end to privilege, the abolition of slavery, equality of rights, and the reign of law. Justice, nothing else; that is the alpha and omega of my argument: to others I leave the business of governing the world.<

In total we find quite different justifications for property in general, namely as a divine gift and derived privileges, as forced usurpation, as the result of work, by contract, by law or as common possession of a family, community, or state. While the former two are rarely defended by law, the latter are kept generally and non-exclusively in modern societies. They found their way even into the U.N. Declaration of Human Rights from 1948 (Art. 4, and 17-19)

The idea that labour generating property is often taken as justification for intellectual property with respect to the inventor or author. But this hypotheses based in natural law is not so self-evident as labour is very often done in some kind of division-especially in the case of modern engineering or scientific research, depending on many prior results- and by that also basis to many subsequent results. The natural law as base for copyright is also not well founded in many cases; think of the complexity of movie production with large teams, or of computer games, or multimedia productions, where there is no more single author - not even a small group of authors. The very concept of authorship becomes a questionable one under these conditions.

\section{Commercially Regulated Intellectual Property}

In the period of early industrialization modern patent law and modern copyright were fixed in England, France, and other countries. These laws fixed the idea of monopolies for the use and commercial exploitation of new and technically useful ideas as patents and of mo-

\footnotetext{
${ }^{6}$ La loi révolutionnaire en matière de propriété littéraire et artistique de 13-19 janvier 1791. It was finally with changes approved in July 19th, 1793.
} 
nopolies for the print and reprint of books. Though monopolies were considered as contrary to the liberal trade these special monopolies of ideas and expression were kept and expanded until nowadays.

Modern Patent law is closely related to the birth of the industrial society. Its modern form goes back to the middle of the 19th century in England, and to comparable laws in the next decades in other industrial areas. Patent law constitutes a trade-off between a time-limited national monopoly of typically 18-20 years of commercial exploitation in exchange to the public disclosure of the patented technical methods (>trade secrets $<$ ) in the patent's specification. In legally defined areas patents may be applied for technical inventions that are new, commercially useful, and non-obvious to the knowledgeable artisan or technician. Basically patents as monopolies are undesirable as they hinder the advancement of technology and industry. Therefore they have to be renewed annually with increasing fees.

Parallel to patent law modern copyright law developed, as a bookseller and printer monopoly in the anglo-american tradition and as a droits d'auteur in continental Europe. Copyright served mainly for the protection of the local printer's investments initially for 14 years, and in some extent also as a control system for the author over the printing of his books. English copyright was furthermore combined with censorship, to be enforced by the London stationer's guild. In the tradition of earlier printer's patents copyright had to be registered.

The French revolution gave birth to a publishing law that focused on the eternal right of the author to be recognized for his work - a reflex of the revolutionary cult of reason and of genius. ${ }^{7}$ The moral right of authorship is fixed in the French tradition very rigidly: The author's rights can never be sold - although its commercial aspects may well be transferred to a publisher. While the subtext of that droit d'auteur was also a measure of censorship, demanding each book to bear the name of its author as well as its printer, it centered on the idea that the author should be able to control the spread of his work. The subtle balance between the author-genius and the public was well perceived by Le Chapelier, who wrote that the author's right to dispose of his work must be interpreted as an exception because >un ouvrage publié est de sa nature une propriété publique.<

Authorship and its rights needed no registration. Initially their distinction was granted lifelong for the author with an extension of 5 or 10 years for the heirs, In 1866 this French law was already extended to 50 years after the death of the author and this was introduced into international treaties from the Berne convention to WIPO and TRIPS, the Trade Related Aspects Intellectual Property Rights, defined by the World Trade Organization WTO. Recently the commercial protection of copyright reaches in some countries as far as 70 years

\footnotetext{
${ }^{7}$ For obvious reasons this 1995 reform was called "Mickey Mouse Law," granting the Disney Corporation another 25 years to commercialize a cartoon figure that otherwise would have escaped into the public domain in 2004 .
} 
after the death of an author end even 95 years after initial grant of copyright for companies in the U.S. ${ }^{8}$

WIPO justifies copyright with the bold statement >Copyright and its related rights are essential to human creativity, by giving creators incentives in the form of recognition and fair economic rewards. Under this system of rights, creators are assured that their works can be disseminated without fear of unauthorized copying or piracy. This in turn helps increase access to and enhances the enjoyment of culture, knowledge, and entertainment all over the world. $<$ But WIPO does not answer the question why this reward for the author should be kept for 50 years after his death. The commercial aspects of copyright are contracts - and as such they are debatable and neither essential nor universal, despite WIPO's noble justifications.

\section{Commercially Unregulated Intellectual Artifacts}

Though there is a growing interest in commercially useful intellectual artifacts, there are still vast areas of unregulated intellectual artifacts. These are clearly visible in all kinds of native culture in the sense of regional cooking, natural healers, herbal remedies, community networks and many other skills.

But it is not only this low-level knowledge that is excluded ${ }^{9}$, it is also high-level knowledge that defies patentability, namely the non-technical aspects of science. The most palpable of these sciences are the most basic: namely mathematics and theoretical physics. As they are usually not directly applicable to technical invention they are non-statuary in regard to the patent law. On the other hand, it is obvious that many results of scientific research are basic to the promotion of technology. As long as universities and academies are financed by state they may and will fulfill their job in research and education for the benefit of society. The more they are forced into directly applicable, patentable research -as it is already in the technological faculties- the more they will close their doors for scientific exchange and basic research - internationally as well as nationally ${ }^{10}$.

Fritz Machlup noted in 1958 in a report to the U.S. Senate: >It has seemed unjust to many, for example, that the inventor of a new gadget should be protected..., while the savant who discovered the principle on which the invention is based should be without protection and without material reward for his services to society. Yet, proposals to extend government protection of intellectual property to scientific discoveries have everywhere been rejected as

\footnotetext{
8 though I cannot ignore that is already a vivid interest in pharmaceutically useful indigene drugs ...

${ }^{9}$ We may see that closure process already by the shadowy scientific research of the military-industrial complex.

${ }^{10}$ Fritz Machlup, An Economic Review of the Patent System,Study No. 15, Subcommittee on Patents, Trademarks and Copyrights of the U.S. Senate Judiciary Committee, 1-2, 20-21, 44-45, 76-80 (1958)
} 
impractical and undesirable. ${ }^{11}$ It would be more than >impractical and undesirable - it would probably result in disaster.

Patents are only applicable for a restricted area of scientific research, namely technology including chemistry and some areas of biotech and medical research, but copyright covers all scientific publications. Usually, with the notable exception of some rare bestsellers, scientific authors are neither rewarded substantially for their literary production nor do they depend on it. But scientists need readers for their career. Considering this, copyright is basically not in the interest of scientific writers and there are notable steps to restrict the influence of copyright for scientific publications like the Los Alamos preprint-servers in physics, mathematics, and computer science (now at Cornell University http://arxiv.org/).

Inside scientific research is a refugium where intellectual property is obeyed generally without clear legal regulations. It is the process of citation, or better of copying ideas with proper citation - or of plagiarism if this is not obeyed. In its simplest form plagiarism ${ }^{12}$ is the verbal copy of some research. This usually violates some copyright. It is much more difficult to define precisely the originality of an idea. A research paper may describe the same conclusions as someone else's. Then its first author is usually considered to be the originator to be cited in all subsequent distribution of that idea. But it is sometimes arguable whether it is really the same idea. A clarifying citation is then considered good style, but this depends somewhat on goodwill and respect. In some fields the same conclusion reached by different investigators may demonstrate a new idea - e.g. in political sciences, while in other fields, like mathematics this usually would be plagiarism (or uninteresting). The first ownership of an idea is sometimes hard to prove and even harder to defend. In a legal sense plagiarism may be of no provable damage to others and will thus not constitute fraud, somewhat contrary to popular belief ${ }^{13}$ - even among scientists. ${ }^{14}$

\footnotetext{
${ }^{11}$ It is the kidnapping of a child or a slave of some roman countryman, an accusation that was first used by Marcus Valerius Martial at a writer who copied some of Martial's verses. Martial wrote in his epigram: >My books need no one to accuse or judge you: the page which is yours stands up against you and says, 'You are a thief.'،

${ }^{12}$ I pointed out elsewhere that plagiarism, especially under the conditions of the internet, may become a virus to scientific truth and by that of scientific reliability and advancement. Cp. W. Coy, Computer Augmented Research and Scientific Misconduct, in K.Brunnstein \& J. Berleur, Human Choice and Computers: Issues of Choice and Quality of Life in the Information Society (Proc. IFIP 17th World Computer Congress), Dordrecht (Holland): Kluwer, 2002

${ }^{13}$ There are now many >academic misbehavior policies « in universities worldwide. Hopefully they will help the less imaginative scientific copyists to learn the basic rules of adequate citation and respect.

${ }^{14} \mathrm{cp}$. Volker Grassmuck, Freie Software - Zwischen Privat- und Gemeineigentum, Bonn: Bundeszentrale für politische Bildung, ${ }^{2} 2004$
} 


\section{Ethical considerations}

Considering the large picture we may find structurally at least five conflicting parties that are interested in the formulation of intellectual property laws. It starts with authors and inventors, that are economically represented by publishers or manufacturers - sometimes through additional agents. On the other side there are clients or buyer of monopolistically protected goods as well the public giving the basis for a technical or literary culture in inventions or arts. This is promoted via education, or public financial or other support of science. And there are state and government putting this whole process into legal national and international frameworks that have to be adapted over and over again.

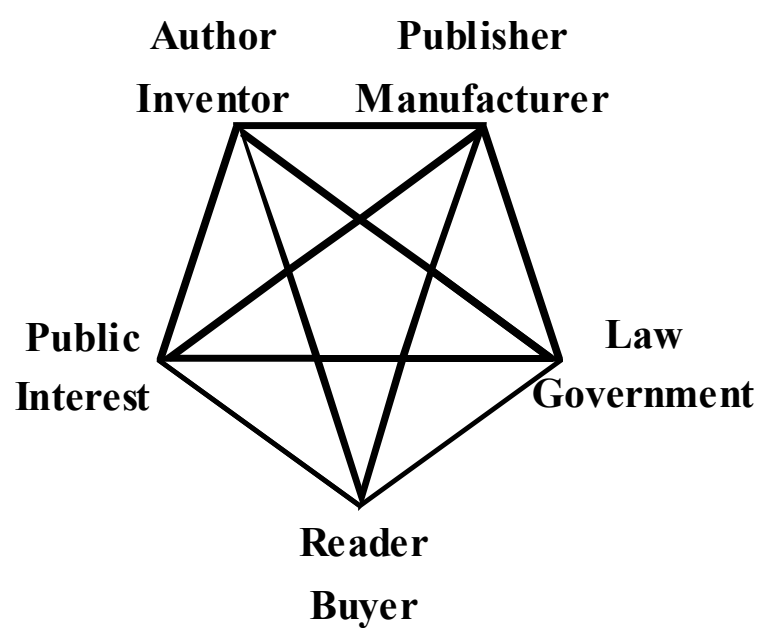

A mesh of interest in intellectual property

Fundamental ideas regulating this adaptive process have to keep in mind national welfare as well as its global aspects. Granting monopolies even time-bounded may protect investments and give some reward for inventors and authors. But that is neither the only way such goals may be achieved nor are there convincing proofs that this is the best way to achieve the undisputed goals of general welfare and advancement of the >useful arts`, technology, science, knowledge, or culture.

\section{Licenses beyond industrial copyright}

Many aspects of these goals would be better served by more flexible processes of granting rights and licenses. As intellectual goods are basically not scarce, they may be given away by a copy process where the owner keeps the property despite the transfer. Information technologies generate economies of plenitude and not economies of misery or scarcity. This is economically the very foundation of information societies.

There is now a large movement towards Open Source programming that interprets programs not as products to be sold, often in shrink-wrapped packages, but as services given to 
the community in order to improve that what was received before. This process is basically not free of costs - but it may be much cheaper than shrink-wrap software as Open Source reflects the vanishing costs of copying and distributing digital data. A driving force in the development of Open Source software are appropriate licenses. Especially the GNU Public License ${ }^{15}$ allows free usage of program sources and its machine readable binary translations but it demands derivatives to be offered mandatory under that same license, ${ }^{16}$ allowing fast distribution of knowledge in that particular field.

But computer source code is not the only work of intellectual expression that has its own public license. There are large repositories of otherwise unpublished materials in the web. Wikipedia, the recently started Free Encyclopedia ${ }^{17}$ is gaining enormous momentum in size as well as in quality with a liberal license of use ${ }^{18}$ - and it gives itself birth to a series of DVD-ROMs and books. Presently (2005) Wikipedia links more than half a million articles. This demonstrates the power of intellectual cooperation once it is unleashed from commercial ties.

Many scientists start now to offer drafts or copies of their work by self archiving on their own e-print servers or on servers of their institution or some scientific societies. Others restrict their copyright for journals to a relatively short period of one or two years. Open Archives spread in the net, constituting a worldwide scientific library. These bottom-up movements are complemented by more top-down efforts like http://scholar.google.com/ and the recent approach by six countries of the European Union to form an electronic treasure of worldwide accessible scholarly texts.

Pushed by Stanford law professor Lawrence Lessig there is now a completely different set of licenses called Creative Commons ${ }^{19}$ that allows the shaping of enhanced copyright licences for numerous countries - licenses that are far more precise than the general book publishers contracts. Creative Commons licenses define such specific questions like allowed or denied use, copy, or modifications of texts, the transfer to the public domain, the duration of the license and much more. Creative Commons are not only for books, but there are video, images, audio, multimedia and education licenses as well.

\footnotetext{
15 The GNU PL is therefore sometimes called the GNU Public Virus.

${ }^{16}$ www.wikipedia.org started in 2001.

${ }^{17}$ Wikipedia is under the The GNU Free Documentation License (GNU FDL or simply GFDL); this is an open content counterpart to the GNU GPL for Open source software.

18 http://creativecommons.org/

${ }^{18}$ Fritz Machlup, op.cit.

${ }^{19}$ But then, as John Maynard Keynes said, >In the long run we are all dead.
} 


\section{Conclusions}

Both patents and copyrights support the fiction of the single dedicated inventor or author, somehow a cult of the genius needing support. While authorship may still be claimed for many books, there is a strong tendency to produce works based on literature and art in complex professional associations. this holds for movie, TV, or music productions, multimedia, or computer games.

Patents are even more the result of planned search and innovation in companies that may work well without them as long as they may keep their production or trade secrets. It is very questionable whether patents in total accelerate technical advancements or whether

they hinder technical advancements. As companies have to deal somehow with the existing laws they must build a patent portfolio in order to be able to cooperate with their competition. It is in this precise sense that >patents become a new currency< as the director general of WIPO announces. Obviously, those without such currency are in the serious disadvantage that they have to pay steep license fees to keep with the technical advancement - if they were granted a license at all. Patents support the technological Haves, and hinder the technological Have nots. How far this is related to the basic idea to spromote the science and useful arts, $<$ as the U.S. constitution claims, is highly questionable. It certainly does not hold in a global scale.

However, it is not easy to get rid of this dilemma. As Fritz Machlup stated already in 1958: If one does not know whether a system as a whole (in contrast to certain features of it) is good or bad, the safest policy conclusion is to 'muddle through'... If we did not have a patent system, it would be irresponsible ... to recommend instituting one. But since we have had a patent system for a long time, it would be irresponsible, on the basis of our present knowledge, to recommend abolishing it. This last statement refers to a country such as the U.S. - not to a small country and not a predominantly nonindustrial country, where a different weight of argument might well suggest another conclusion.<

Unfortunately, history took another turn until now. Though there are good reasons to restrict the spread of commercial claims in the field of ideas and expressions we have to observe the contrary: stricter protection, longer periods of monopoly, growing numbers of the protection cases. The commercial pressure of corporates and supportive governments is high, but grassroot movements demonstrate the viability of alternative licenses like Creative Commons or GNU Open Source GPL and many others. While we can find no strong moral evidence for the present state of intellectual property laws, there is still the open question how to achieve the optimal use of ideas and art for a maximum of people worldwide. For the time being we may keep as a not too comfortable insight:

In the long term all published ideas and expressions belong to the public. 


\section{Literature}

Charles Babbage, On the Decline Science in England, London: Fellowes, 1830

Bruce W. Bugbee, Genesis of American patent and Copyright Law, Washington: Public Affairs Press, 1967

Wolfgang Coy, Computer Augmented Research and Scientific Misconduct, in K.Bunnstein \& J. Berleur, Human Choice and Computers: Issues of Choice and Quality of Life in the Information Society (Proc. IFIP 17th World Computer Congress), Dordrecht (Holland): Kluwer, 2002

Volker Grassmuck, Freie Software - Zwischen Privat- und Gemeineigentum, Bonn: Bundeszentrale für politische Bildung, ${ }^{2} 2004$

Immanuel Kant, Metaphysik der Sitten, 1797

William M. Landes, \& Robert A. Posner, The Economic Structure of Intellectual Property Law, Cambridge (Mass.) e.a.: The Balknap Press of Harvard University Press, 2003

Lawrence Lessig, Code and other laws of cyberspace, New York: Basic Books, 1999

Lawrence Lessig, Free Culture - How big media uses technology and the law to lock down culture and control creativity, New York: The Penguin Press, 2004

Lawrence Lessig, The future of ideas - The fate of the commons in a connected world, New York: Random House 2001

John Locke, Two Treatises of Government, Ch. V. "Of Property”, 1690

Fritz Machlup, An Economic Review of the Patent System,Study No. 15, Subcomm. Patents, Trademarks and Copyrights of the U.S. Senate Judiciary Comm., 1958

Jean-Jacques Rousseau, A Dissertation On the Origin and Foundation of the Inequality of Mankind, 1755

Pierre-Joseph Proudhon, Qu'est-ce que la propriété? Recherche sur le principe du droit et du gouvernement, 1840. 